\title{
Secondary metabolites (essential oils) from sand-dune plants induce cytotoxic effects in cancer cells
}

\author{
Ellie Beeby ${ }^{\mathrm{a}, 1}$, Mariana Magalhães ${ }^{\mathrm{b}, \mathrm{c}, 1}$, Juliana Poças ${ }^{\mathrm{a}, \mathrm{d}, 1}$, Thomas Collins $^{\mathrm{a}}$, Marco F.L. Lemos ${ }^{\mathrm{d}}$, \\ Lillian Barros $^{\mathrm{e}}$, Isabel C.F.R. Ferreira ${ }^{\mathrm{e}}$, Célia Cabral ${ }^{\mathrm{b}, \mathrm{c}, \mathrm{f}, *}$, Isabel M. Pires ${ }^{\mathrm{a}, * *}$ \\ ${ }^{a}$ Department of Biomedical Sciences, Faculty of Health Sciences, University of Hull, HU6 7RX, UK \\ ${ }^{\mathrm{b}}$ University of Coimbra, Coimbra Institute for Clinical and Biomedical Research (iCBR), Faculty of Medicine, 3000-548 Coimbra, Portugal \\ ${ }^{\mathrm{c}}$ University of Coimbra, Center for Innovative Biomedicine and Biotechnology (CIBB), 3000-548 Coimbra, Portugal \\ ${ }^{\mathrm{d}}$ MARE - Marine and Environmental Sciences Centre, Instituto Politécnico de Leiria, ESTM, 2520-630 Peniche, Portugal

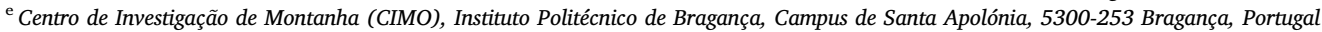 \\ ${ }^{\mathrm{f}}$ Centre for Functional Ecology, Department of Life Sciences, University of Coimbra, Calçada Martim de Freitas, 3000-456 Coimbra, Portugal
}

\section{A R T I C L E I N F O}

\section{Keywords:}

Sand-dune plants

Essential oils

Natural products

Antitumoral properties

\begin{abstract}
A B S T R A C T
Ethnopharmacological relevance: Despite advances in modern therapeutic strategies, cancer remains the second leading cause of death worldwide. Therefore, there is a constant need to develop more efficient anticancer targeting strategies. The anticancer therapeutic proprieties of medicinal plants and their bioactive compounds have been reported for several years, making natural extracts and/or compounds derived from these a promising source of novel anticancer agents. Sand dune plants are subjected to severe environmental stresses, leading to the development of adaptations, including the production of secondary metabolites with a wide range of bioactivities, such as: anti-inflammatory, analgesic, antiseptic, hypoglycaemic, hypotensive, antinociceptive, antioxidant and anticancer.

Aim of the study: The anticancer potential of sand dune plants remains under-investigated, so this research describes the characterisation of the composition of bioactive EOs from sand-dune plants of Peniche (Portugal), and assessment of their activity in vitro and potential mechanism of action.

Materials and methods: EOs were extracted from six sand-dune species of plants from Peniche sand dunes: Crithmum maritimum L., Seseli tortuosum L., Artemisia campestris subsp. maritima (DC.) Arcang., Juniperus phoenicea var. turbinata (Guss.) Parl., Otanthus maritimus (L.) Hoffmanns. \& Link, and Eryngium maritimum L.. EOs composition was fully characterised chemically using Gas Chromatography-Mass Spectrometry (GC-MS). The assessment of anticancer activity and mechanism of action was performed in vitro using breast and colorectal cancer 2D and 3D spheroid cell line models, through cell proliferation assay, western blotting analysis, and cell cycle analysis.

Results: EOs from the majority of the species tested (S. tortuosum, A. campestris subsp. maritima, O. maritimus, and E. maritimum) were mainly composed by hydrocarbon compounds (sequisterpenes and monoterpenes), showing antiproliferative activity in both $2 \mathrm{D}$ and 3D models. EO extracted from $S$. tortuosum and O. maritimus were identified as having the lowest $\mathrm{IC}_{50}$ values for both cell lines when compared with the other species tested. Furthermore, this antiproliferative activity was associated with increased p21 expression and induction of apoptosis.

Conclusions: The present study suggests that EOs extracted from $S$. tortuosum and O. maritimus present promising cytotoxic properties. Further evaluation of the extracts and their key components as potential anticancer agents should therefore be explored.
\end{abstract}

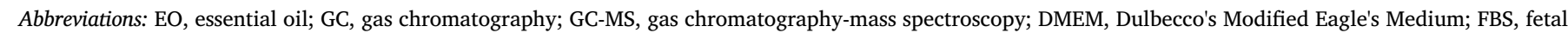

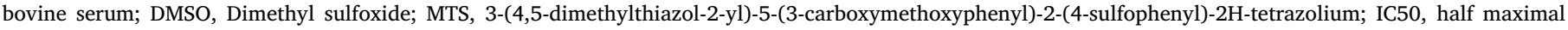

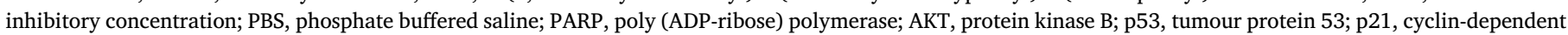

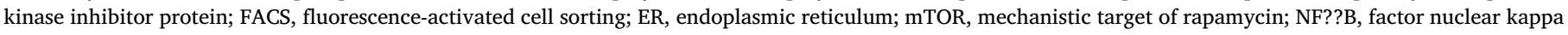
B

* Corresponding author. Faculty of Medicine, University of Coimbra, Pólo das Ciências da Saúde, Azinhaga de Santa Comba, 3000, Coimbra, Portugal.

*** Corresponding author.

E-mail addresses: celia.cabral@fmed.uc.pt (C. Cabral), i.pires@hull.ac.uk (I.M. Pires).

${ }^{1}$ These authors equally contributed to this work. 


\section{Introduction}

Cancer remains the second leading cause of death worldwide, responsible for 8.7 million deaths per year, even though improvements in diagnosis and treatment strategies and an increased understanding of tumour biology (Fitzmaurice et al., 2017; Nagai and Kim, 2017). Cancer development and progression is driven by a series of genetic and epigenetic alterations that lead to a dysregulated cell proliferation, survival, and invasiveness, promoted by cell cycle progression deregulation, angiogenesis, metabolic switch, and resistance to apoptosis (Roos et al., 2016; Sever and Brugge, 2015). Conventional anticancer therapeutic strategies continue to mostly rely on either radiotherapy or conventional chemotherapy approaches (Miller et al., 2016). Interestingly, several of these chemotherapy compounds are either directly derived from plant extracts or chemically modified versions of specific phytoproducts, including conventional chemotherapy agent taxol/paclitaxel (Blowman et al., 2018). Plants and their bioactive compounds have been used in the treatment of disease since ancient times. An increasingly expanding body of research has demonstrated that plant-derived products have promising anti-inflammatory, anti-bacterial, anti-oxidant, and anticancer effects, with fewer side-effects than other compounds (Blowman et al., 2018; Cabral et al., 2017; Dhifi et al., 2016). EO (essential oil) phytoproducts comprise multifunctional chemical compounds extracted from aromatic plants and are responsible for the great majority of therapeutic activity attributed to these plants (Edris, 2007; Sharifi-Rad et al., 2017). EOs are secondary metabolites, mainly constituted by oxygenated compounds and hydrocarbons, in which the proportion and concentration of the complex mixture will determine the biological activity of the EO (Blowman et al., 2018; Gautam et al., 2014). Some of the main chemical constituents of EOs are terpenes, which are associated with various biological activities, including anticancer proprieties (Dhifi et al., 2016).

Vegetation patterns in coastal sand dunes hold particular interest for ecologists, in part because of their clear interaction with the dune geomorphology (Cowles, 1911). Coastal sand dunes are subjected to severe environmental stresses and disturbance, caused by salinity, drought, nutrient limitation, substrate instability, sand burial, wind abrasion, erosion of the coastline and storms (Gornish and Miller, 2010).

Sand-dune species, due to their understudied and unexplored stress adaptation mechanisms and strategies present an opportunity for the discovery of new bioactive molecules (Murray et al., 2013). However, although work in this field has expanded in the last few years, the role of EOs as potential anti-cancer agents is still not fully explored (Gautam et al., 2014; Bhalla et al., 2013). The aromatic plants present in the sand dunes of Peniche, chosen for this research are described below.

The genus Artemisia L. is widespread throughout the world, growing wild over the Northern Hemisphere and belongs to the Asteraceae family. Artemisia campestris subsp. maritima (DC.) Arcang. grows in Coastal sands, usually in primary dunes (Djeridane et al., 2007). This species has been used as febrifuge, vermifuge, against digestive troubles, gastric ulcer, menstrual pain (Dob et al., 2005; Djeridane et al., 2007) and for medicinal uses, such as antispasmodic and antihelmintic (Naili et al., 2010).

Crithmum maritimum L., commonly known as sea fennel or rock samphire, is a perennial member of the Apiaceae family (Meot-Duros et al., 2010). It has been attributed many interests in traditional medicine, including diuretic, antiscorbutic, digestive and purgative properties, and can be consumed as a condiment (Atia et al., 2006).

The genus Eryngium L. belongs to the family Apiaceae and includes around 250 species that are widespread throughout the world (Darriet et al., 2014). Among them, several Eryngium species have been used as ornamental plants, condiments or in traditional medicine (Küpeli et al., 2006; Darriet et al., 2014). Eryngium maritimum L., usually named 'sea holly' in England or 'Panicaut desmers' in France, grows wild on the sandy beaches of western Europe, the Mediterranean basin and the Black Sea (Küpeli et al., 2006a; Darriet et al., 2014). The plant is one of the typical dune species implicated in the plant network that contributes to sand dune edification and restoration (Darriet et al., 2014). E. maritimum has also been reported to exhibit different therapeutic uses in folk medicine (Küpeli et al., 2006a).
The genus Juniperus L. (Cupressaceae) has approximately 70 species in the Northern Hemisphere (Nakanishi et al., 2004; Seca and Silva, 2005). Juniperus phoenicea var. turbinata (Guss.) Parl. is a bush growing in relatively dry conditions in stabilized dunes and coastal cliffs, but also on rocky slopes thermophilic, limestone outcrops and embedded river valleys (Seca and Silva, 2005). Plants of the genus Juniperus are used in different European cuisines as spice and flavouring alcoholic drinks, as well as in cosmetics (Loizzo et al., 2008). These plants have an extensive history of use in global folk medicine for various disorders, such as common colds, urinary and kidney infections and dermatological disorders (Allen and Hatfield, 2004). Many biological activities have been reported for Juniperus sp. including anti-inflammatory (Akkol et al., 2009; Lesjak et al., 2011), diuretic, antiseptic (bacterial and fungal) (Cavaleiro et al., 2006; Ennajar et al., 2009), anthelmintic (Kozan et al., 2006), hypoglycaemic (Ju et al., 2008), hypotensive, abortifacient, antinociceptive (Akkol et al., 2009), antiviral (Sassi et al., 2008), anticancer (Kusari et al., 2011), anti-oxidant (Lesjak et al., 2011) and analgesic properties (Lesjak et al., 2011).

Otanthus maritimus (L.) Hoffmans. \& Link belongs to the family Asteraceae. This species has been employed in folk medicine in decoctions as tonics, dyspeptics and for the treatment of toothache, asthmatic bronchitis, dysentery and inflammation of the urinary bladder (Reutter, 1923; Tsoukatou et al., 2000). In 2013, Cabral and collaborators evaluated the anti-inflammatory activity in vitro and comproved this bioactivity of the essential oil (Cabral et al., 2013).

Seseli tortuosum L. belongs to the family Apiaceae, which is composed of aromatic herbs and economically important species that are used as foods, spices, condiments and ornamentals (Lawrence, 1995; Crowden et al., 1969; Pimenov \& Leonov 1993). Several Seseli species are reported in ancient literature for various healing effects, namely herbal remedy for human inflammation, swelling, rheumatism, pain and common cold. In Turkish folk medicine, the fruit of Seseli tortuosum is used as emmenagogue and antiflatulent (Baytop, 1999). This EO have been investigated for its various biological properties including anti-inflammatory, antinociceptive (Küpeli et al., 2006b; Tosun et al., 2006) and antifungal activities (Gonçalves et al., 2012).

Bearing in mind that inflammation is a well established key hallmark of cancer and has a key role in promoting tumorigenesis (Hanahan and Weinberg, 2011), and taking into account that these sand-dune plants from Peniche: A. campestris subsp. maritima, C. maritimum, E. maritimum, J. phoenicea var. turbinata, $O$. maritimus and $S$. tortuosum have anti-inflammatory properties, this study aims to assess the anticancer properties of the essential oils (EOs) of these plants. EO extracts from these six species were tested as potential cytotoxic agents using $2 \mathrm{D}$ and $3 \mathrm{D}$ in vitro models of cancer, as well as, in a non-cancer cell line to evaluate off-target risks. Mechanisms of action of the EOs presenting the most pronounced cytotoxic effect were further evaluated regarding the impact on key signalling pathways involved in cell survival, cell cycle regulation, and cell death mechanisms.

\section{Materials and Methods}

\subsection{Plant materials}

Plant samples were collected from the sand dunes of Consolação beach, Peniche, Portugal. The aerial parts of the six species were collected during the flowering stage (July). The voucher specimens were identified by a plant taxonomist (Célia Cabral) and deposited in the Herbarium of Medicinal Plants, Faculty of Pharmacy, University of Coimbra, under the numbers: J. Poças 02013 (A. campestris subsp. maritima), J. Poças 06013 (C. maritimum), J. Poças 02013 (E. maritimum), J. Poças 05013 (J. phoenicea var. turbinata), J. Poças 01013 (O. maritimus), and J. Poças 04013 (S. tortuosum).

\subsection{Extraction of essential oils}

EOs were isolated by hydrodistillation for $3 \mathrm{~h}$ using a Clevengertype apparatus, according to the procedure described in the European Pharmacopoeia (Council of Europe, 1997). Extracts were stored in glass vials at $4{ }^{\circ} \mathrm{C}$ in the dark. 


\subsection{Chemical characterisation of essential oils using Gas Chromatography-} Mass Spectrometry (GC-MS)

EOs were analysed by gas chromatography (GC) for quantification of extract components, and GC coupled with mass spectrometry (GC-MS) for identification of EOs components, as previously described (Falcão et al., 2018). In brief, the GC-MS unit consisted on a PerkinElmer system with a Clarus ${ }^{\circledast} 580 \mathrm{GC}$ module and a Clarus $^{\circledR}$ SQ $8 \mathrm{~S}$ MS module, equipped with DB-5MS fused-silica column $(30 \mathrm{~m} \times 0.25 \mathrm{~mm}$ i.d., film thickness $0.25 \mu \mathrm{m}$; J\&W Scientific, Inc.). Oven temperature was programmed, $45-175^{\circ} \mathrm{C}$, at $3{ }^{\circ} \mathrm{C} / \mathrm{min}$, subsequently at $15^{\circ} \mathrm{C} / \mathrm{min}$ up to $300^{\circ} \mathrm{C}$, and then held isothermal for $10 \mathrm{~min}$; injector and detector temperatures, $280^{\circ} \mathrm{C}$. The transfer line temperature was $280^{\circ} \mathrm{C}$; ion source temperature, $220^{\circ} \mathrm{C}$; carrier gas, helium, adjusted to a linear velocity of $30 \mathrm{~cm} / \mathrm{s}$; split ratio, 1:40; ionization energy, $70 \mathrm{eV}$; scan range, 40-300 u; scan time, $1 \mathrm{~s}$. The software Turbomass (software version 6.1.0, PerkinElmer, Shelton, CT, USA) for Windows was used for data acquisition. The identity of the components was assigned by comparison of their retention indices, relative to $\mathrm{C} 7-\mathrm{C} 40 \mathrm{n}$-alkane indices and GC-MS spectra from a commercial MS database. Compounds were quantified as area percentages of total volatiles using the relative values directly obtained from peak total ion current (TIC). Analyses were performed in triplicate.

\subsection{Cell line culture and treatment}

HEK293-T cell line (human embryonic kidney), RKO cell line (colorectal cancer), and MCF7 cell line (breast cancer) were purchased from ATCC and ECCAC, respectively. Cells were cultured in Dulbecco's Modified Eagle's Medium (DMEM; Biowest) supplemented with 10\% fetal bovine serum (FBS; Gibco) and $1 \%$ sodium pyruvate (Biowest). Cells were maintained at $37^{\circ} \mathrm{C}$ and $5 \% \mathrm{CO}_{2}$, in a humidified incubator. All cell lines were routinely tested as negative for mycoplasma. For the various experimental setups, cells (2D or 3D models) were treated with a range of concentrations of EOs or the cytotoxic agent Doxorubicin hydrochloride (Sigma Aldrich). DMSO (Dimethyl sulfoxide) was used as a vehicle control when relevant.

\subsection{Spheroid generation, treatment, and imaging}

Spheroids were grown using MCF7 cells, seeded at a density of $2 \times 10^{4}$ cells per well in ultra-low adherence round-bottomed 96-well plates (Corning). At least 12 spheroids were generated per condition. After aggregation, spheroids were treated and media was replaced every 2 days for a total duration of 14-day treatment. Spheroids were imaged using the GelCount instrument (Oxford Optronix), and spheroid size was determined using the Image J software (NIH), as previously reported (Pires et al., 2012; Schneider et al., 2012).

\subsection{Cell viability and growth inhibition evaluation}

Cell viability was evaluated through 3-(4,5-dimethylthiazol-2-yl)-5-(3carboxymethoxyphenyl)-2-(4-sulfophenyl)-2H-tetrazolium (MTS) assay, using the CellTiter $96^{\circledR}$ Aqueous One solution Cell proliferation assay (Promega) as per manufacturer's instructions. In brief, cells were seeded at a density $2 \times 10^{4}$ (HEK293-T), $1 \times 10^{4}$ (RKO), and $5 \times 10^{3}$ (MCF7) cells per well in a 96-well plate. After $24 \mathrm{~h}$, cells were treated with either vehicle (DMSO) diluted in media, or a serial dilution of EOs in media or with the cytotoxic agent Doxorubicin. EOs were initially diluted in DMSO in a 1:4 ratio (EO/DMSO). This was further diluted in media in order to obtain a $1 \mu \mathrm{L} / \mathrm{ml}$ concentration, and further diluted 1:10 in order to obtain a range of EO concentrations $\left(1 \mu \mathrm{L} / \mathrm{ml}-10^{-5} \mu \mathrm{L} / \mathrm{ml}\right) .48 \mathrm{~h}$ post-treatment, media was removed and replaced with fresh culture medium containing MTS reagent solution. Cells were further incubated at $37{ }^{\circ} \mathrm{C}$ and $5 \% \mathrm{CO}_{2}$. After $4 \mathrm{~h}$, the absorbance of the plate was read at $490 \mathrm{~nm}$ in a microplate reader (Bioteck ELx800). Growth inhibition was determined as the percentage of viable cells in relation to untreated cells. IC $_{50}$ (half maximal inhibitory concentration) values were calculated using GraphPad Prism Software (GraphPad Software).

\subsection{Fluorescence-activated cell sorting (FACS) cell cycle analysis}

Cells (adherent and floating) were harvested, the cell pellet was resuspended in 1X PBS, and the cell suspension fixed in 70\% Ethanol in 1X PBS. Cells were washed in 1X PBS and incubated in 1X PBS with $10 \mu \mathrm{g} / \mathrm{ml}$ of propidium iodide (Sigma) and $100 \mu \mathrm{g} / \mathrm{ml}$ of RNAse (Sigma). FACS analysis was performed previously reported (Pires et al., 2010), using a FACS Calibur analyzer (BD Biosciences). Data were analysed using the ModFIT software (Verity Software House).

\subsection{Cell lysis and western blot analysis}

Whole cell lysates were prepared as previously described (Poujade et al., 2018). Briefly, cells were washed with PBS $1 \mathrm{X}$ and detached mechanically. Detached cells were also collected. Cell pellets were resuspended with UTB lysis buffer (9M Urea, $75 \mathrm{mM}$ Tris-HCl pH 7.5 and $0.15 \mathrm{M} \beta$-mercaptoethanol). Lysates were sonicated and clarified, and protein concentration was determined using a NanoDrop spectrophotometer (ND-1000 version 3.5.2). $50 \mu \mathrm{g}$ were loaded in SDS-PAGE gels and processed for western blotting. The antibodies used for Western blot analysis were anti-p53 DO1 (Santa Cruz Biotechnology), anti-p21, anti-PARP, anti-pAKT, anti-total AKT (Cell Signalling Technology). Anti $\beta$-actin (Santa Cruz Biotechnology) was used as loading control. Further antibody details are present in Supplementary Table 1. Membranes were developed using the Fluorescent Imager ChemiDoc system and the Imager Lab software (Biorad). Densitometric analysis of band intensity relative to the $\beta$-actin loading control bands and the vehicle only control samples was performed using ImageJ software (NIH) (Schneider et al., 2012).

\subsection{Statistical analysis}

All the experiments were performed using triplicates, being representative of at least three independent experiments (replication is noted in Figure legends). Results are expressed as mean \pm SD, unless otherwise noted. Statistical significance was determined by Student's $t$ test (one variable) or 2-way ANOVA with Tukey post hoc multiple comparison test using GraphPad Prism (GraphPad Software). $* p<0.05 ;{ }^{* *} p<0.01 ; * * * p<0.001 ;{ }^{* * * *} p<0.0001$.

\section{Results}

\subsection{Essential oils composition}

Yield and main compounds for each species are summarized in Table 1. The extracted EOs had variable yields for the different species, ranging between $0.08 \%$ (E. maritimum) and $0.66 \%$ (S. tortuosum). The highest yields were obtained for $S$. tortuosum and A. campestris subsp. maritima with values of $0.66 \%$ and $0.47 \%$, respectively. Additionally, the descriptive analysis of EOs composition showed that $S$. tortuosum and $J$. turbinata EOs are mainly composed by monoterpenes (Tables S2C and S2F; Figs. S1C and S1F). The same is verified for C. maritimum and O. maritimus EOs, which are also composed by monoterpenes (Tables S2B and S2E; Figs. S1B and S1E). Meanwhile, E. maritimum EO is mainly constituted by sesquiterpenes, contrary to $A$. campestris subsp. maritima EO which presents a composition based on a mixture of monoterpenes and sesquiterpenes (Tables S2D and S2A; Figs. S1D and S1A).

\subsection{Evaluation of the cytotoxic effect of EOs extracts from the six dune plant species panel}

The potential antitumor activity of the EO extracts from the six species was initially evaluated using the MTS proliferation/viability assay. MCF7 (breast) and RKO (colorectal) cancer cells were treated for $72 \mathrm{~h}$ with a serial dilution range of concentrations of extracted EOs, starting at $1 \mu \mathrm{L} / \mathrm{ml}$. Cell viability was determined in relation to control samples (cells treated with DMSO). EOs extracted from $O$. maritimus, $S$. tortuosum, A. campestris subsp. 
maritima, and E. maritimum exhibited a pronounced antiproliferative/antiviability effect in both cell lines (Fig. 1A and B, Table 2), as compared with the known chemotherapy agent Doxorubicin ( $\mathrm{IC}_{50}$ of $0.08 \mu \mathrm{M}$, Figs. S2-S3). Interestingly, EOs extracted from C. maritimum and $J$. turbinata did not exhibit a significant cytotoxic effect in either cell lines, as relative proliferative capacity did not drop below $70 \%$ of control. IC $_{50}$ (inhibitory concentration needed to reduce proliferation/viability by $50 \%$ compared to control) values for each EO extract were also determined (Table 2). S. tortuosum and $O$. maritimus EOs presented the lowest $\mathrm{IC}_{50}$ concentration values for the $\mathrm{RKO}$ cell line, 0.034 and $0.34 \mu \mathrm{l} / \mathrm{mL}$ respectively. The outcome was similar for MCF7 cells, with EOs obtained from $S$. tortuosum, O. maritimus, and $E$. maritimum having the lowest $\mathrm{IC}_{50}$ concentrations $(0.0086,0.21$, and $0.15 \mu \mathrm{l}$ / $\mathrm{mL}$, respectively). Additionally, all extracts had a reduced cytotoxic effect in non-cancer cells HEK-293 T relatively to the observed in cancer cell lines, indicating a potential therapeutic window between cancer and non-cancer cell treatment with the EO extracts (Fig. S4). These data indicate that EOs extracted from $O$. maritimus, S. tortuosum, A. campestris subsp. maritima, and E. maritimum induced a robust antiproliferative/anti-viability activity in cancer cell lines in vitro.

MCF7 (A) and RKO (B) cells were seeded at a density of $1 \times 10^{4}$ and $5 \times 10^{3}$ cells per well in a 96-well plate, respectively. Triplicate wells were seeded per condition. Cells were treated with a range of EO concentrations (1:10 serial dilution $1 \mu \mathrm{L} / \mathrm{ml}-10^{-5} \mu \mathrm{L} / \mathrm{ml}$ ). Vehicle-only controls were prepared by diluting DMSO in media at $1 \mu \mathrm{L} / \mathrm{ml}$. Cells were exposed to EO treatment for $72 \mathrm{~h}$ and an MTS assay was subsequently performed. Scatter plots (A, B) represent cell viability expressed as percentage survival of control ( $\mathrm{n}=3$ independent experiments). $\mathrm{IC}_{50}$ values for both cell lines ( $\mathrm{n}=3$ independent experiments) are noted in Table 2.

\subsection{Impact of treatment with EOs from the six dune plant species panel on} in vitro $3 D$ cancer models

As four species were identified as having potential anti-proliferative activity using the MTS assay, it was important to determine the efficacy of all EO extracts in tumour microenvironmental-relevant models. For this, multicellular spheroid models, derived from cancer cell lines, are well established as in vitro 3D models to be used to test the therapeutic efficacy of novel agents (Zanoni et al., 2016). MCF7 spheroids were treated with the different EO extracts for 15 days (with treatment replenished every 2-3 days), during which spheroid size was determined (Fig. 2). As it can be observed, a decrease in spheroid volume in relation to the vehicle control (DMSO) was observed for all species, with the exception of C. maritimum EO extracts (Fig. 2B). The impact on spheroid volume varied between species, with the most pronounced effects observed for O. maritimus, E. maritimum, S. tortuosum, and J. turbinata EOs, with a reduction of spheroid volume of more than $50 \%$ by 14 days (Fig. 2C-G). Furthermore, O. maritimus and E. maritimum EO extract treatment led to a clear reduction in spheroid volume and integrity even after 6 days of treatment (Fig. 2C, F, and G). These data show that $O$. maritimus, E. maritimum, and $S$. tortuosum EO extracts also have an antiproliferative/anti-viability effect in more complex 3D in vitro models.

MCF7 3D spheroids were established from $2.5 \times 10^{4}$ cells/well. 12 spheroids were established per condition. Spheroids were treated with either vehicle-only control ( $1 \mu \mathrm{L} / \mathrm{ml}$ DMSO in media) or $1 \mu \mathrm{L} / \mathrm{ml}$ EO extracts from the 6 dune plants in media. Treatment was maintained for 15 days, with medial refreshed regularly. Spheroids were imaged every 3 days and spheroid volume was determined. (A-F) Histograms representing the mean spheroid volume ( $\mathrm{n}=3$ independent experiments): (A) A. campestris subsp. maritima, (B) C. maritimum, (C) E. maritimum, (D) J. phoenicia var. turbinata, (E) O. maritimus, and (F) S. tortuosum. ${ }^{*} p<0.05 ;{ }^{* *} p<0.01 ;{ }^{* * *} p<0.001$ (G) Representative images of treated spheroids at days 0,6 , and 15.

\subsection{Evaluation of the mechanism of action of S. tortuosum and $O$. maritimum $E O$ extracts}

S. tortuosum and O. maritimus EO products were selected as the best leads for further evaluation from our initial six species plant panel. This was due to the EO extracts from these two species having the highest extraction yields and lowest $\mathrm{IC}_{50}$ values. In order to evaluate the mechanism of action of these extracts, two approaches were undertaken. Firstly, the impact of treatment with these extracts on cell cycle regulation was evaluated using flow cytometry (Fig. 3 and Table 3). Secondly, the impact of EO treatment on survival, cell cycle, and apoptosis signalling pathways were analysed using western blotting (Fig. 4 and Fig. S5). For both these approaches, MCF7 cells were treated with $1 \mu \mathrm{l} / \mathrm{mL}$ EOs from $S$. tortuosum and $O$. maritimus for 24 and $48 \mathrm{~h}$. Treatment with $2 \mu \mathrm{M}$ Doxorubicin was used as a positive control, as this is a well-established conventional chemotherapy agent. The results in Fig. 3 indicate there was no clear trend in changes in cell cycle distribution after EO extract treatment, albeit a significant decrease $(* * * \mathrm{p}<0.005$ and $* \mathrm{p}<0.05)$ in the percentage of cells in the G1 phase after treatment with $S$. tortuosum $(24 \mathrm{~h})$ and $O$. maritimus $(48 \mathrm{~h})$ was observed. Interestingly, although there are no observable alterations of p53 levels, p21 protein expression is significantly upregulated in EO-treated samples (Fig. 4A and Figs. S5A-B). This contrasted with treatment with Doxorubicin, which, as expected, had a clear impact on cell cycle distribution, including a decrease of cells in G1/S phases and increase in G2/M phase, p53 stabilization and increase in p21 expression, denoting a clear G2/M cell cycle arrest (Figs. 3-4, Table 3, and Fig. S5C). Importantly, an increase in the sub-G1 population (which can be associated with decreased viability through apoptosis induction) for EO treated samples was also observed, particularly for O. maritimum (Fig. 3 and Table 3). In order to clarify if this is occurring via increased apoptosis, PARP cleavage, a marker of apoptosis downstream of caspase activation, was evaluated for all conditions using western blotting (Fig. 4 and Fig. S5). A significant decrease in total PARP (PARP) levels and a significant increase in cleaved PARP (cPARP) levels was observed for all samples (Fig. 4A-B, Figs. S5A-B). These data indicate that loss of viability is potentially occurring via induction of apoptosis. Finally, as there was no clear stabilization of p53 in EO-treated cells, the impact of EO extract treatment on other survival signalling pathways was also evaluated (Fig. 4). For this, AKT and phospho-AKT levels were analysed using western blotting, as AKT signalling is associated with both pro-survival and anti-apoptosis regulation (Kalimuthu and Se-Kwon, 2013). It was observed that, although there were no observable alterations in total AKT levels after treatment, there is a significant decrease in total phospho-ATK levels (Fig. 4A).

In summary, these data indicate that treatment with EOs extracted from both $S$. tortuosum and $O$. maritimus did not induce a significant cell cycle arrest response, albeit leading to increased p21 levels. However, EO extract treatment increased pro-apoptotic signalling, concomitant with decrease in pro-survival AKT expression. This indicates that the antiproliferative/anti-viability effect observed after treatment with these extracts can be underpinned by an increase in apoptotic cell death via AKT.

MCF7 cells were treated for 24 and $48 \mathrm{~h}$ with either vehicle-only

Table 1

Main components of EO extracts.

\begin{tabular}{|c|c|c|}
\hline Species & Yield (\%) & Main compounds (above 10\%) \\
\hline Artemisia campestris subsp. maritima & 0.47 & $\beta$-pinene isomer $1, \gamma$-Muurolene \\
\hline Crithmum maritimum & 0.36 & $\gamma$-terpinene, thymol methyl ether isomer 2 , o-Cymene isomer $1, \beta$-Phellandrene isomer 1 \\
\hline Eryngium maritimum & 0.08 & 7-Tetracyclo [6.2.1.0 (3.8)0 (3.9)]undecanol, 4,4,11,11-tetramethyl-, D-germacrene \\
\hline Juniperus turbinata subsp. turbinata & 0.29 & $\alpha$-pinene, $\beta$-phellandrene isomer 2 \\
\hline Otanthus maritimus & 0.12 & Chrysanthenone isomer 1 , Verbenyl acetate \\
\hline Seseli tortuosum & 0.66 & $\alpha$-pinene, $\beta$-pinene isomer 1 \\
\hline
\end{tabular}



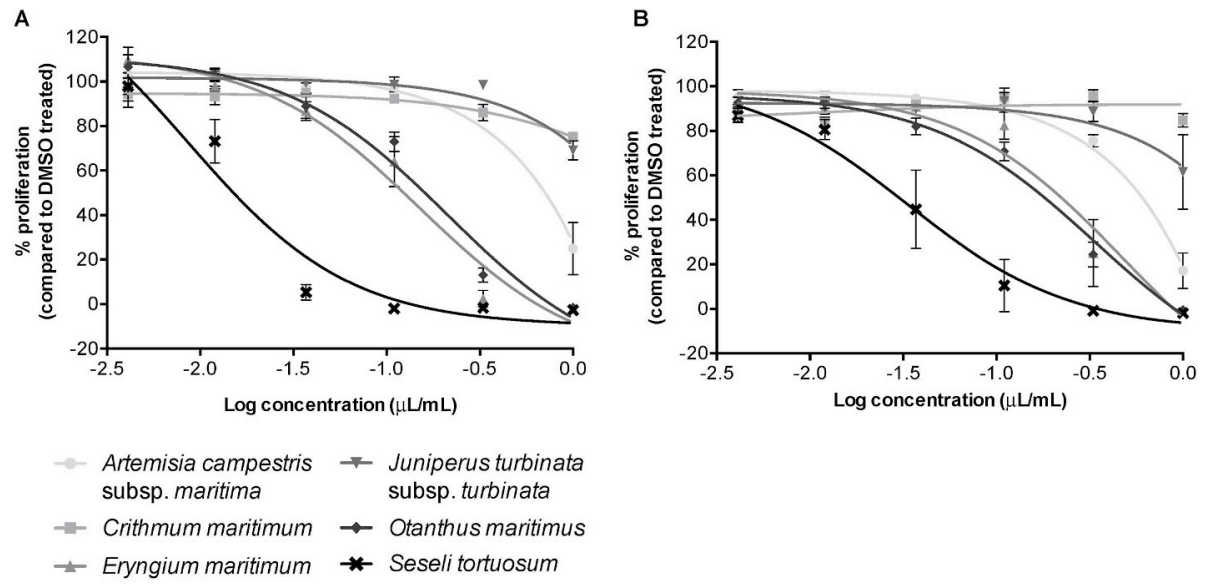

Fig. 1. Cytotoxic effect of EOs extracts from the 6 dune plant species panel.

Table 2

Cytotoxic effect of EOs extracts from the 6 dune plant species panel: $\mathrm{IC}_{50}$ values for both cell lines.

\begin{tabular}{lll}
\hline Species & \multicolumn{2}{l}{$\mathrm{IC}_{50}(\mu \mathrm{L} / \mathrm{mL})$} \\
\cline { 2 - 3 } \cline { 3 - 3 } & MCF7 & RKO \\
\hline Artemisia campestris subsp. maritima & 0.32 & 0.35 \\
Crithmum maritimum & $\mathrm{ND}$ & $\mathrm{ND}$ \\
Eryngium maritimum & 0.15 & 0.47 \\
Juniperus turbinate subsp. turbinata & $\mathrm{ND}$ & $\mathrm{ND}$ \\
Otanthus maritimus & 0.21 & 0.34 \\
Seseli tortuosum & 0.0086 & 0.034 \\
\hline
\end{tabular}

control ( $1 \mu \mathrm{L} / \mathrm{ml}$ DMSO in media), $1 \mu \mathrm{L} / \mathrm{ml} S$. tortuosum, $1 \mu \mathrm{L} / \mathrm{ml} O$. maritimum EO extracts, or $2 \mu \mathrm{M}$ Doxorubicin. Samples were analysed by flow cytometry for DNA content. (A-C) Proportion of cells in the different cell cycle phases (G1, S, G2/M), as well as subG1 cell debris content (SubG1) is presented as percentages of total cell population. Stacked bar graphs represent means for $\mathrm{n}=3$ independent experiments. Statistical significance of differences between means of vehicle control vs EO for both species, per timepoint and cell cycle phase is noted on Table 2. (D-F) Representative FACS analysis histograms from $\mathrm{n}=3$ independent experiments of $S$. tortuosum (D), O. maritimus (E), and Doxorubicin (F) treatments. Key: i) Vehicle control 24 h; ii) EO/ Doxorubicin $24 \mathrm{~h}$; iii) Vehicle control $48 \mathrm{~h}$; ii) EO/Doxorubicin $48 \mathrm{~h}$.

MCF7 cells were treated with either vehicle-only control $(1 \mu \mathrm{L} / \mathrm{ml}$
A

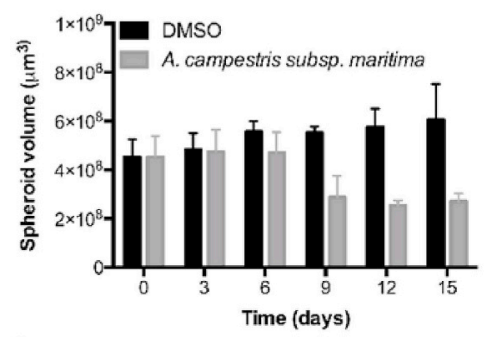

C

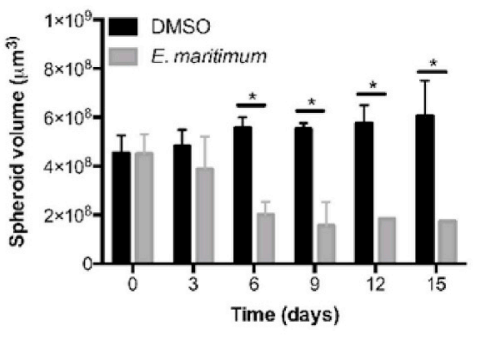

E

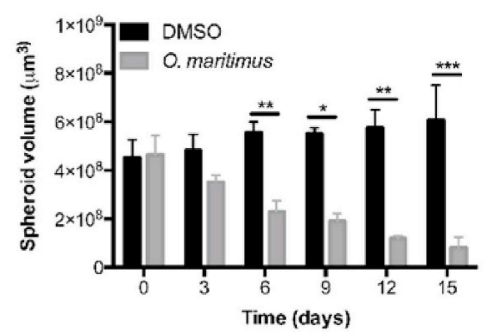

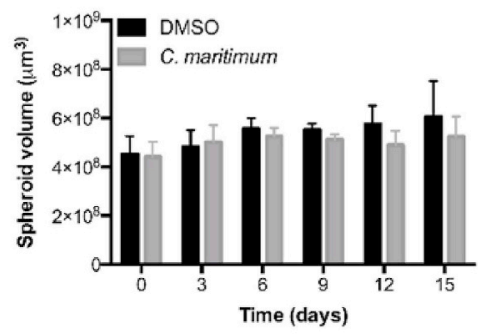

D

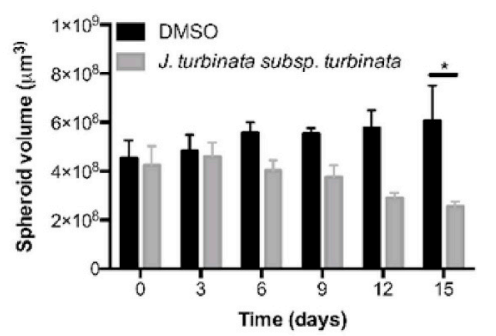

F

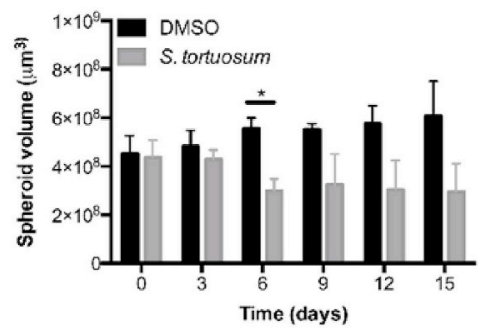

G
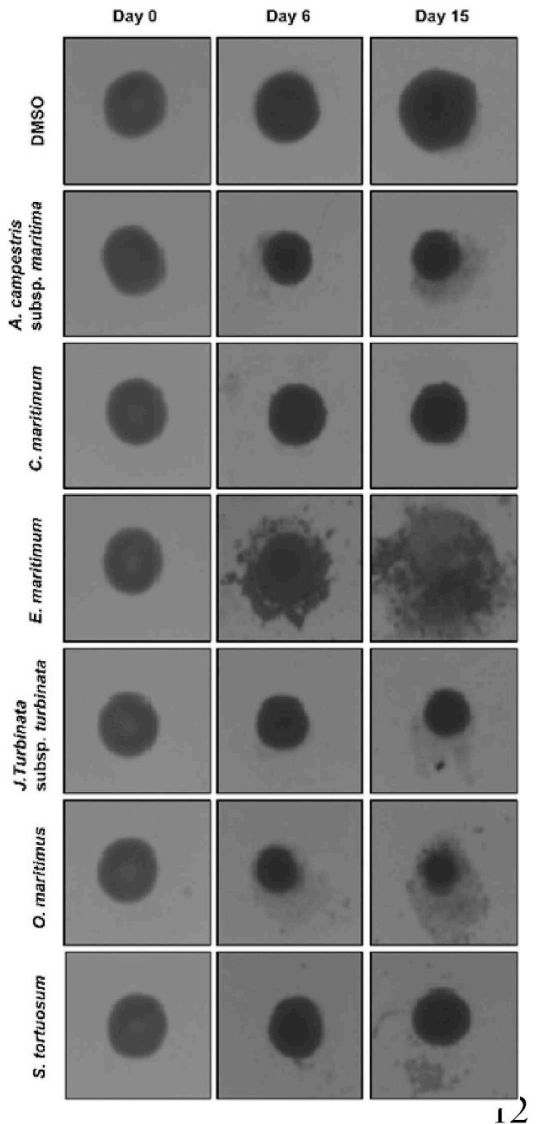

Fig. 2. Impact of treatment with EOs from the 6 dune plant species panel on in vitro 3D cancer models. 
A
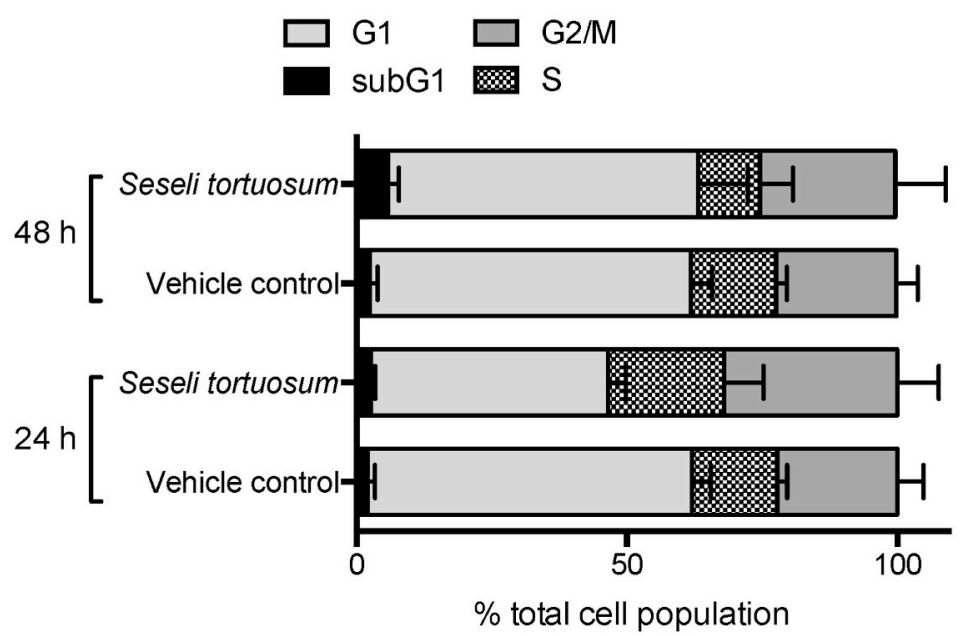

B

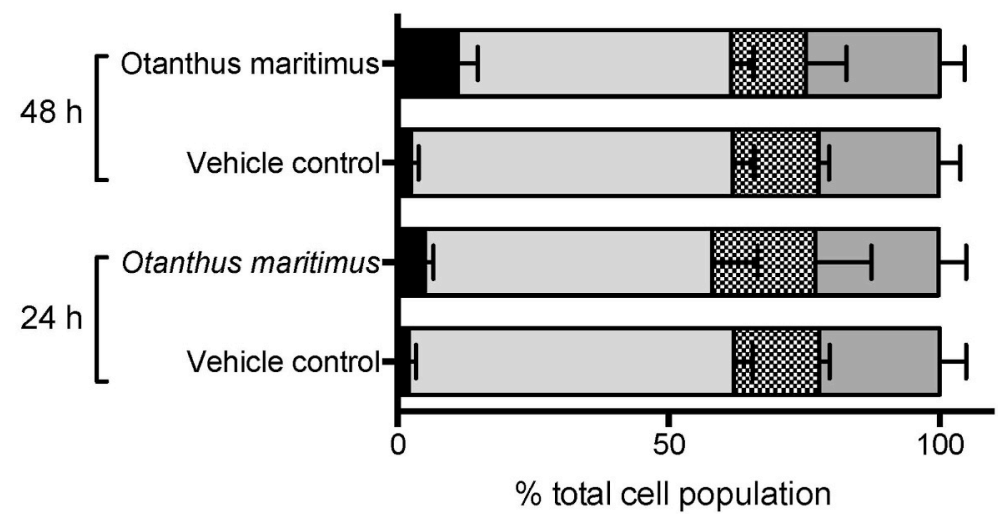

C

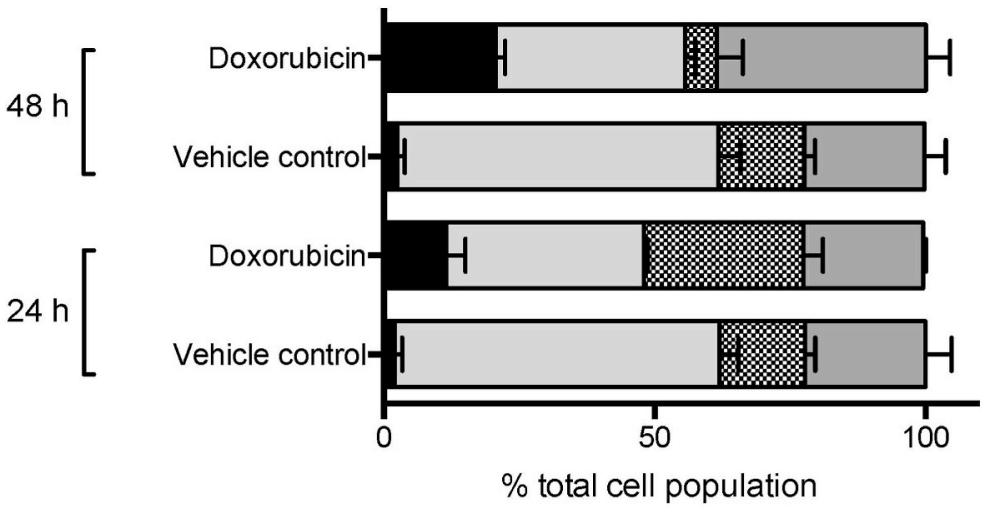

D

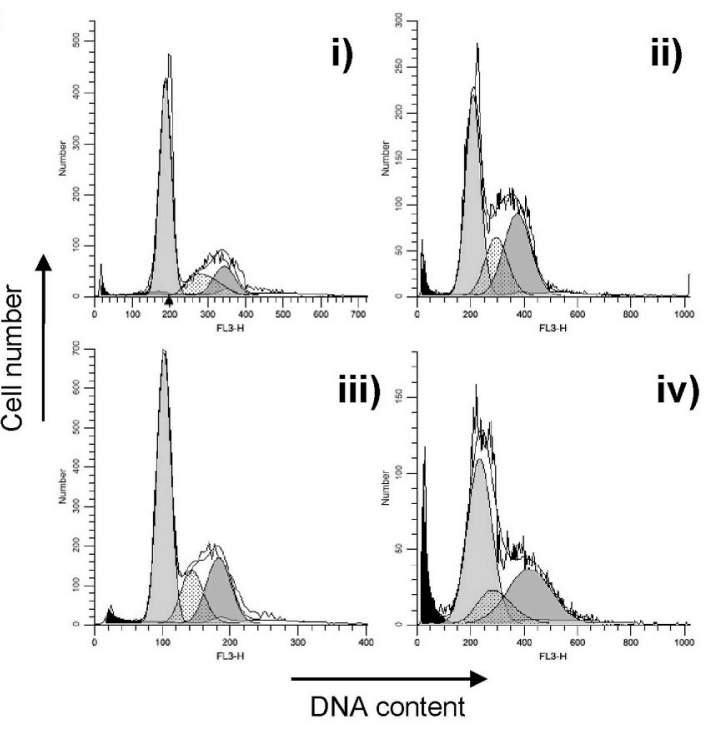

E

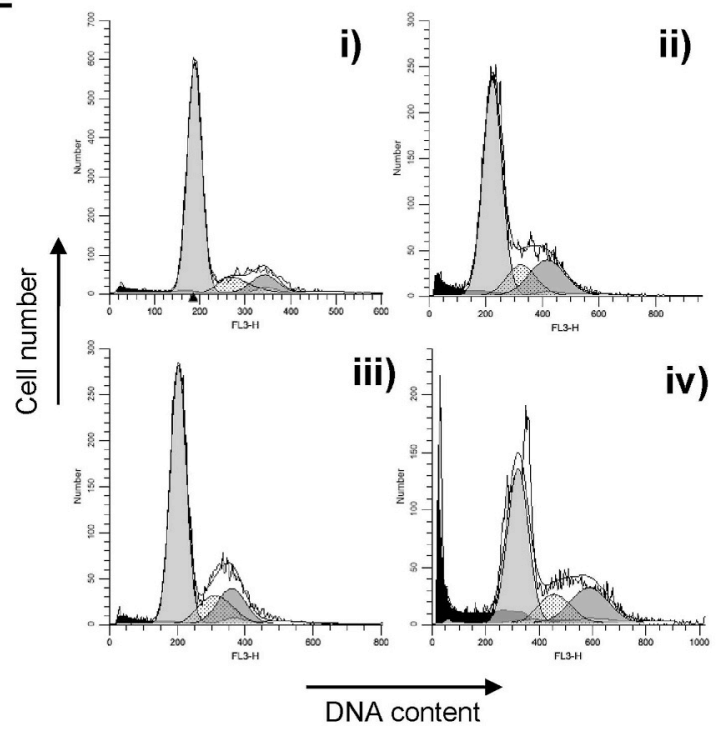

$\mathbf{F}$

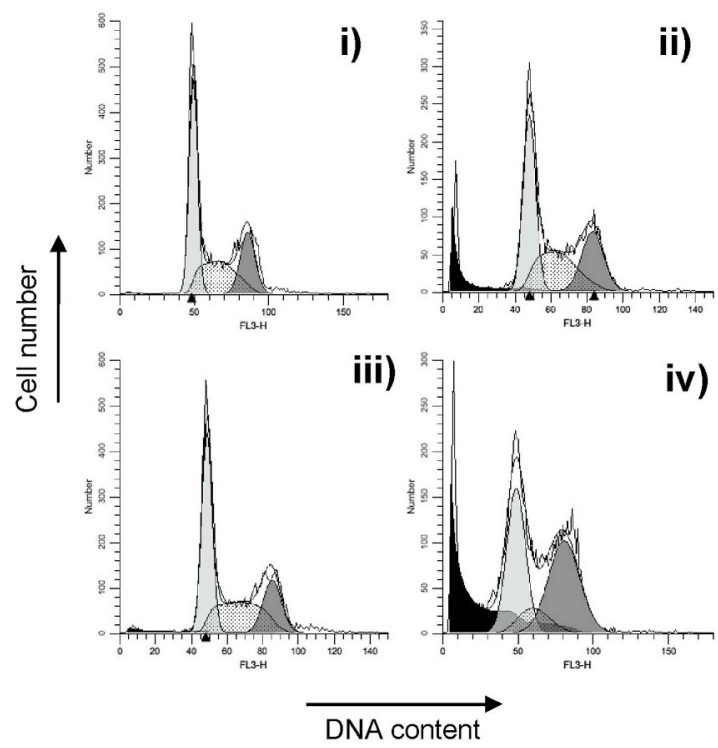

Fig. 3. Impact of $O$. maritimus and $S$. tortuosum EO extract treatment on cell cycle progression. 
Table 3

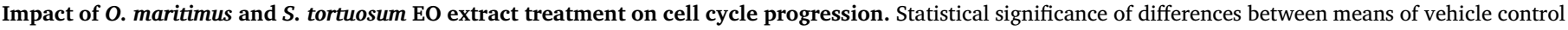
vs EO for both species, per timepoint and cell cycle phase.

\begin{tabular}{|c|c|c|c|c|c|}
\hline & & subG1 & G1 & $S$ & $\mathrm{G} 2 / \mathrm{M}$ \\
\hline Vehicle only $v s$ Seseli tortuosum & $24 \mathrm{~h}$ & $\mathrm{p}>0.05$ & ${ }^{*} \mathrm{p}<0.05$ & $\mathrm{p}>0.05$ & $\mathrm{p}>0.05$ \\
\hline Vehicle only $v s$ Seseli tortuosum & $48 \mathrm{~h}$ & $\mathrm{p}>0.05$ & $\mathrm{p}>0.05$ & $\mathrm{p}>0.05$ & $\mathrm{p}>0.05$ \\
\hline Vehicle only $v$ s Othantus maritimus & $24 \mathrm{~h}$ & $\mathrm{p}>0.05$ & $\mathrm{p}>0.05$ & $\mathrm{p}>0.05$ & $\mathrm{p}>0.05$ \\
\hline Vehicle only vs Othantus maritimus & $48 h$ & $* * \mathbf{p}<0.01$ & ${ }^{*} \mathbf{p}<0.05$ & $\mathrm{p}>0.05$ & $\mathrm{p}>0.05$ \\
\hline Vehicle only vs Doxorubicin & $24 \mathrm{~h}$ & $* \mathbf{p}<0.05$ & $* * * * p<0.0001$ & $* * \mathbf{p}<0.01$ & $\mathrm{p}>0.05$ \\
\hline Vehicle only vs Doxorubicin & $48 \mathrm{~h}$ & $* * * * \mathbf{p}<0.0001$ & $* * * * \mathrm{p}<0.0001$ & $* \mathbf{p}<0.05$ & $* * * * p<0.0001$ \\
\hline
\end{tabular}

A
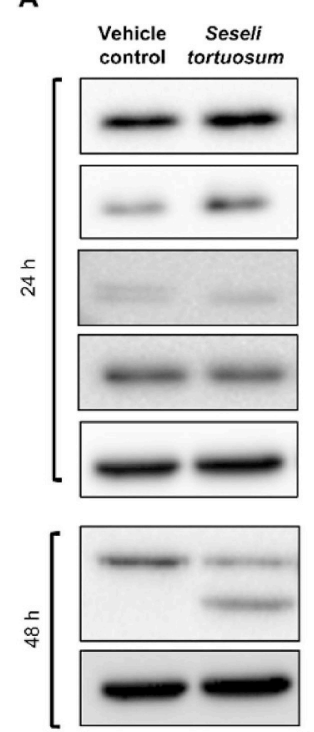

Vehicle Otanthus control maritimum
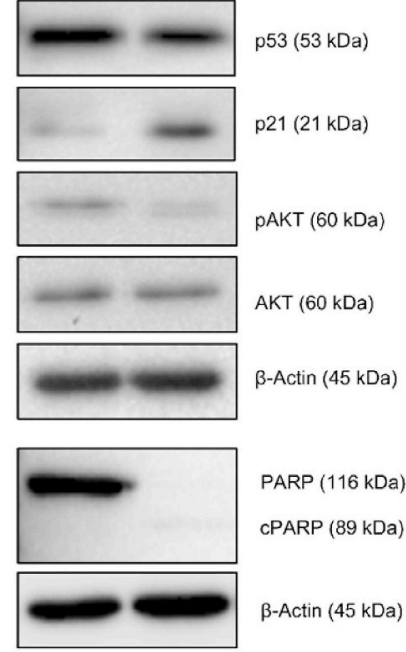

PARP (116 kDa)

B
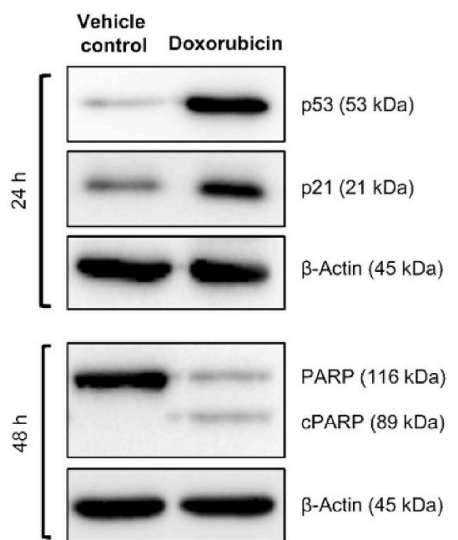

Fig. 4. Impact of $O$. maritimus and $S$. tortuosum treatment on cell survival and cell death signalling.

DMSO in media), $1 \mu \mathrm{L} / \mathrm{ml} S$. tortuosum or O. maritimum EO extracts (A) or vehicle control $/ 2 \mu \mathrm{M}$ Doxorubicin (B) for 24 and $48 \mathrm{~h}$ p53, p21, phospho-AKT, total AKT, and PARP levels were analysed by Western blotting. $\beta$-actin was used as loading control. Representative blots of $\mathrm{n}=3$ independent experiments are shown.

\section{Discussion}

Since ancient times plants have been used in medicine to treat different pathologies. Consequently, this traditional use conducted to an increasing interest in the study of plants bioactive compounds as potential therapeutic agents (Asadi-Samani et al., 2016). Moreover, phytoproducts, such as EOs, containing active chemical compounds have been one of the main target focus for the design of novel anticancer therapies (Blowman et al., 2018; Dhifi et al., 2016; Gautam et al., 2014).

Based on that, this work aimed to assess the anticancer activity of EOs extracted from six species of sand-dune plants, containing in their chemical composition several compounds that have known therapeutic activity. The present study has shown that EOs from $S$. tortuosum, $O$. maritimus, and E. maritimum induced a significant decrease in cell viability and/or proliferation, both in $2 \mathrm{D}$ and $3 \mathrm{D}$ in vitro cancer models, and presented the lowest $\mathrm{IC}_{50}$ values of the panel of species. This cytotoxic effect exhibited a profile similar to that with the conventional chemotherapy agent Doxorubicin. These results were somehow expected, as these EOs mixtures have in their composition compounds with previously described anticancer effects and present relative low cytotoxicity effect in non-cancer cells treated with the same concentrations of EOs.

All compounds identified in the EOs of the species studied are either predominantly monoterpenes (C. maritimum; J. turbinata; O. maritimus; and $S$. tortuosum), sesquiterpenes (E. maritimum), or a mix of both these hydrocarbon compounds (A. campestris) (Table 1). Previous studies have reported anticancer activity induced by sesquiterpenes and monoterpenes, via apoptosis and promotion of antiproliferative effect in cancer cell lines (Asadi-Samani et al., 2016; Bhalla et al., 2013). Furthermore, Sylvestre and colleagues analysed the chemical composition of Myrica gale EOs collected into two fractions during extraction (30 and $60 \mathrm{~min}$ ) and its anticancer effect. The higher percentage of compounds detected were monoterpenes (30 min fraction) and sesquiterpenes (60 min fraction), with the $60 \mathrm{~min}$ fraction showing a higher anticancer activity associated with decreased cell viability (Sylvestre et al., 2005). A study by Lone and colleagues showed that EO extracted from the leaf of Senecio graciliflorus was able to induce a strong therapeutic effect against human lung cancer cell lines, with this activity attributed to the main components of the EO, $\alpha$-pinene (a monoterpene also present in $S$. tortuosum in the present study) and ocimene (Lone et al., 2014). In another study, Ramadan and coworkers showed that Egyptian juniper oil, containing $26.19 \%$ of $\alpha$-pinene, was associated with a more pronounced anticancer effect against HepG2, MCF7, and A549 cancer cell lines when compared with the commonly used chemotherapeutic drug, Doxorubicin (Ramadan et al., 2015). E. maritimum EO was shown to be composed predominantly by sesquiterpenes, including germacrene D. A recent study investigating the activity of EOs from Magnolia grandiflora flowers, containing in majority monoterpenes and sesquiterpenes, including germacrene $\mathrm{D}$ (sesquiterpene present in $\mathrm{E}$. maritimum $\mathrm{EO}$ ) and $\beta$-pinene (monoterpene present in A. campestris and S. tortuosum EOs) induced a cytotoxic effect against various cancer cell lines (Morshedloo et al., 2017). Furthermore, several studies have indicated that monoterpenes identified in O. maritimus EOs, such as chrysanthenone, are also components of extracts from other species reported to have anticancer activities, such as Pulicaria incisa and Artemisia herba-alba (Shahat et al., 2017; Tilaoui et al., 2015). All the described works support the potential anticancer activity attributed to the main compounds observed in the extracted EOs. However, it was not possible, at this stage, to evaluate whether specific compounds, or mixture of components, are responsible for the observed antiproliferative effects.

$S$. tortuosum and $O$. maritimus were further investigated to elucidate if the 
effect was cytostatic (solely impact on cell proliferation) or cytotoxic (increased cell death). EOs from another species, E. maritimum, had a similar impact on cell proliferation relative to the other two species, although the EO extraction had a much lower yield, so was not further investigated. Our data showed that the effect of the treatment with $O$. maritimum and $S$. tortuosum were mostly associated with a cytotoxic effect underpinned by decreased survival signalling and increased apoptosis. Previous studies support these results, once they reported that the monoterpene components $\alpha$-pinene, $\beta$ pinene, and chrysanthenone have cytotoxic effect in cancer cells through proapoptotic proprieties and the impact in the regulation of AKT pathway (Suhail et al., 2011; Zhou et al., 2007). No significant impact on cell cycle progression was observed for both $O$. maritimum and $S$. tortuosum EOs, even though there was an increase of p21 levels, which presented a slight discrepancy with the literature, as $\alpha$ - and $\beta$-pinene, some of the main compounds of $S$. tortuosum EO, are known to be involved in cell cycle arrest (Suhail et al., 2011). Thus, the results showed that $O$. maritimum and $S$. tortuosum EOs most probably predominantly induced loss of viability via induction of apoptosis. This antitumoral mechanism of action differs from the positive control Doxorubicin, which induces apoptosis subsequent to DNAdamage induced double-strand breaks and cell cycle arrest (Tacar et al., 2013). EOs from other species previously reported to possess anticancer properties to induce loss of viability and/or antiproliferative mechanisms through a series of mechanisms, including direct impact on mitochondrial potential activating the intrinsic apoptotic pathway, ER-stress signalling activation, inhibition of survival pathways such as mTOR or NF??B signalling, or increased oxidative stress (Girola et al., 2015; Hassan et al., 2010; Seal et al., 2012). Therefore, future work will focus on further exploring the mechanism of action of $S$. tortuosum and $O$. maritimus regarding their cytotoxic and pro-apoptotic activity. Of particular interest are the components of $\mathrm{O}$. maritimus, none of which have been reported in the literature to have anticancer effects. Future work will also focus on evaluating the role of specific components of EOs vs. the original complex extract mixtures, and any potential impact of these in combination with more conventional therapeutic approaches, such as conventional chemotherapy and radiotherapy, both in vitro and in vivo.

To our knowledge, this is the first study proposing this class of phytoproducts, i.e. EOs, from $S$. tortuosum and $O$. maritimus, as potential and promising agents against cancer cells in vitro. These two EO mixtures show a pronounced cytotoxic effect against cancer cells, through decreased survival signalling and induction of apoptosis.

\section{Conclusion}

Our study is the first to propose EO phytoproducts from $S$. tortuosum and $O$. maritimus as potential and promising anti-cancer agents. These two EOs show a cytotoxic effect against cancer cells, through decreased survival signalling and induction of apoptosis.

\section{List of the authors and respective contributions}

Experiments were carried out by EB, JP, LB, and CC. Data analysis was carried out by TC, IF, CC, and IMP. IMP and CC designed the experiments, with contribution from JP. MM, CC, and IMP wrote the paper with contributions and editing by all other authors. Funding was secured by ML, CC, and IMP.

\section{Declaration of competing interest}

The authors declare no conflict of interest regarding the publication of this paper.

\section{Acknowledgments}

We would like to thank the support provided by the following funders: Higher Education Funding Council for England (HEFCE) through the
University of Hull, U.K.; Foundation for Science and Technology (FCT, Portugal), through the Strategic Projects: UID/MAR/04292/2019 (MARE), UID/NEU/04539/2013 and UID/NEU/04539/2019 (CNC.IBILI), UIDB/ 04539/2020 and UIDP/04539/2020 (CIBB); Foundation for Science and Technology (FCT, Portugal) and FEDER under Programme PT2020 for financial support to CIMO (UID/AGR/00690/2019); Foundation for Science and Technology (FCT, Portugal) project POINT4PAC (SAICTPAC/0019/ 2015-LISBOA-01-0145-FEDER-016405); EASME Blue Labs project AMALIA (EASME/EMFF/2016/1.2.1.4/03/SI2.750419), European Union; Integrated Programme of SR\&TD "SmartBioR" (reference Centro-01-0145-FEDER000018), co-funded by Centro (2020) program, Portugal 2020, European Union, through the European Regional Development Fund.

\section{Appendix A. Supplementary data}

Supplementary data to this article can be found online at https:// doi.org/10.1016/j.jep.2020.112803.

\section{References}

Akkol, E.K., Güvenç, A., Yesilada, E., 2009. A comparative study on the antinociceptive and anti-inflammatory activities of five Juniperus taxa. J. Ethnopharmacol. 125 (2), 330-336.

Allen, D.E., Hatfield, G., 2004. Medicinal Plants in Folk Tradition- An Ethnobotany of Britain \& Ireland. Timber Press, Cambridge, pp. 431.

Asadi-Samani, M., Kooti, W., Aslani, E., Shirzad, H., 2016. A Systematic review of Iran's medicinal plants with anticancer effects. J. Evidence-Based Complement. Alternative Med. 21, 143-153. https://doi.org/10.1177/2156587215600873.

Atia, A., Ben, H.K., Debez, A., Abdelly, C., 2006. Salt and seawater effects on the germination of Crithmum maritimum. In: Biosaline Agriculture and Salinity Tolerance in Plants. Birkhäuser Verlag, Switzerland, pp. 29-33.

Baytop, T., 1999. Therapy with medicinal plants in Turkey past and present, 2nd ed. Nobel Tip Kitabevi, Istanbul.

Bhalla, Y., Gupta, V.K., Jaitak, V., 2013. Anticancer activity of essential oils: a review. J. Sci. Food Agric. 93, 3643-3653. https://doi.org/10.1002/jsfa.6267.

Blowman, K., Magalhães, M., Lemos, M.F.L., Cabral, C., Pires, I.M., 2018. Anticancer properties of essential oils and other natural products. Evidence-based Complement. Alternative Med. 2018, https://doi.org/10.1155/2018/3149362.

Cabral, C., Cavaleiro, C., Gonçalves, M.J., Cruz, M.T., Lopes, M.C., Salgueiro, L., 2013. Otanthus maritimus (L.) Hoffmanns. \& Link as a source of a bioactive and fragrant oil. Ind. Crop. Prod. 43, 484-489.

Cabral, C., Miranda, M., Gonçalves, M.J., Cavaleiro, C., Cruz, M.T., Salgueiro, L., 2017. Assessment of safe bioactive doses of Foeniculum vulgare Mill. essential oil from Portugal. Nat. Prod. Res. 31, 2654-2659. https://doi.org/10.1080/14786419.2017.1292266.

Cavaleiro, C., Pinto, E., Gonçalves, M.J., Salgueiro, L., 2006. Antifungal activity of Juniperus essential oils against dermatophyte, Aspergillus and Candida strains. J. Appl. Microbiol. 100 (6), 1333-1338.

Council of Europe, 1997. European Pharmacopoeia, third ed. Council of Europe, Strasbourg.

Cowles, H.C., 1911. The causes of vegetational cycles. Ann. Assoc. Am. Geogr. 1, 3-20.

Crowden, R.K., Harborne, J.B., Heywood, V.H., 1969. Chemosystematics of the umbelliferae - a general survey. Phytochemistry 8 (10), 1963-1984.

Darriet, F., Andreani, S., De Cian, M.C., Costa, J., Muselli, A., 2014. Chemical variability and antioxidant activity of Eryngium maritimum L. essential oils from Corsica and Sardinia. Flavour Frag. J. 29 (1), 3-13.

Dhifi, W., Bellili, S., Jazi, S., Bahloul, N., Mnif, W., 2016. Essential oils' chemical characterization and investigation of some biological activities: a critical review. Medicines 3, 25. https://doi.org/10.3390/medicines3040025.

Djeridane, A., Yousfi, M., Nadjemi, B., Vidal, N., Lesgards, J.F., Stocker, P., 2007. Screening of some Algerian medicinal plants for the phenolic compounds and their antioxidant activity. Eur. Food Res.Technol. 224 (6), 801-809.

Dob, T., Dahmane, D., Berramdane, T., Chelghoum, C., 2005. Chemical Composition of the Essential Oil of Artemisia campestris. L. from Algeria. Pharm. Biol. 43 (6), 512-514.

Edris, A.E., 2007. Pharmaceutical and therapeutic Potentials of essential oils and thei individual volatile constituents: a review. Phyther. Res. 21, 308-323. https://doi. org $/ 10.1002 /$ ptr.2072.

Ennajar, M., Bouajila, J., Lebrihi, A., Mathieu, F., Abderraba, M., Raies, A., Romdhane, A., 2009. Chemical composition and antimicrobial and antioxidant activities of essential oils and various extracts of Juniperus phoenicea L. (Cupressaceae). J. Food Sci. 74 (7), 364-371.

Falcão, S., Bacém, I., Igrejas, G., Rodrigues, P.J., Vilas-Boas, M., Amaral, J.S., 2018. Chemical composition and antimicrobial activity of hydrodistilled oil from juniper berries. Ind. Crop. Prod. 124, 878-884. https://doi.org/10.1016/j.indcrop.2018.08.069.

Fitzmaurice, C., Allen, C., Barber, R.M., Barregard, L., Bhutta, Z.A., Brenner, H., Dicker, D.J., Chimed-Orchir, O., Dandona, R., Dandona, L., Fleming, T., Forouzanfar, M.H., Hancock, J., Hay, R.J., Hunter-Merrill, R., Huynh, C., Hosgood, H.D., Johnson, C.O., Jonas, J.B., Khubchandani, J., Kumar, G.A., Kutz, M., Lan, Q., Larson, H.J., Liang, X., Lim, S.S., Lopez, A.D., MacIntyre, M.F., Marczak, L., Marquez, N., Mokdad, A.H., Pinho, C., Pourmalek, F., Salomon, J.A., Sanabria, J.R., Sandar, L., Sartorius, B., Schwartz, S.M., Shackelford, K.A., Shibuya, K., Stanaway, J., Steiner, C., Sun, J., Takahashi, K., Vollset, S.E., Vos, T., Wagner, J.A., Wang, H., Westerman, R., Zeeb, H., Zoeckler, L., Abd-Allah, F., Ahmed, M.B., Alabed, S., Alam, N.K., Aldhahri, S.F., Alem, G., Alemayohu, M.A., Ali, R., Al-Raddadi, R., Amare, A., Amoako, Y., Artaman, A., Asayesh, H., Atnafu, N., Awasthi, A., Saleem, H.B., Barac, A., Bedi, N., Bensenor, I., Berhane, A., Bernabé, E., 
Betsu, B., Binagwaho, A., Boneya, D., Campos-Nonato, I., Castañeda-Orjuela, C., CataláLópez, F., Chiang, P., Chibueze, C., Chitheer, A., Choi, J.Y., Cowie, B., Damtew, S., Das Neves, J., Dey, S., Dharmaratne, S., Dhillon, P., Ding, E., Driscoll, T., Ekwueme, D. Endries, A.Y., Farvid, M., Farzadfar, F., Fernandes, J., Fischer, F., Ghiwot, TT, Gebru, A., Gopalani, S., Hailu, A., Horino, M., Horita, N., Husseini, A., Huybrechts, I., Inoue, M., Islami, F., Jakovljevic, M., James, S., Javanbakht, M., Jee, S.H., Kasaeian, A., Kedir, M.S., Khader, Y.S., Khang, Y.H., Kim, D., Leigh, J., Linn, S., Lunevicius, R., El Razek, H.M.A., Malekzadeh, R., Malta, D.C., Marcenes, W., Markos, D., Melaku, Y.A., Meles, K.G., Mendoza, W., Mengiste, D.T., Meretoja, T.J., Miller, T.R., Mohammad, K.A., Mohammadi, A., Mohammed, S., Moradi-Lakeh, M., Nagel, G., Nand, D., Le Nguyen, Q., Nolte, S., Ogbo, F.A., Oladimeji, K.E., Oren, E., Pa, M., Park, E.K., Pereira, D.M., Plass, D., Qorbani, M., Radfar, A., Rafay, A., Rahman, M., Rana, S.M., Søreide, K., Satpathy, M., Sawhney, M., Sepanlou, S.G., Shaikh, M.A., She, J., Shiue, I., Shore, H.R., Shrime, M.G., So, S., Soneji, S., Stathopoulou, V., Stroumpoulis, K., Sufiyan, M.B., Sykes, B.L., TabarésSeisdedos, R., Tadese, F., Tedla, B.A., Tessema, G.A., Thakur, J.S., Tran, B.X., Ukwaja, K.N., Chudi Uzochukwu, B.S., Vlassov, V.V., Weiderpass, E., Wubshet Terefe, M., Yebyo, H.G., Yimam, H.H., Yonemoto, N., Younis, M.Z., Yu, C., Zaidi, Z., Zaki, M.E.S., Zenebe, Z.M., Murray, C.J.L., Naghavi, M., 2017. Global, regional, and national cancer incidence, mortality, years of life lost, years lived with disability, and disability-adjusted life-years for 32 cancer groups, 1990 to 2015: a systematic analysis for the Global Burden of Disease Study. JAMA Oncol 3, 524-548. https://doi.org/10.1001/jamaoncol.2016.5688.

Gautam, N., Mantha, A.K., Mittal, S., Gautam, N., Mantha, A.K., Mittal, S., 2014. Essential oils and their constituents as anticancer agents: a mechanistic view. BioMed Res. Int., e154106. https://doi.org/10.1155/2014/154106. 2014.

Girola, N., Figueiredo, C.R., Farias, C.F., Azevedo, R.A., Ferreira, A.K., Teixeira, S.F., Capello, T.M., Martins, E.G.A., Matsuo, A.L., Travassos, L.R., Lago, J.H.G., 2015 Camphene isolated from essential oil of Piper cernuum (Piperaceae) induces intrinsic apoptosis in melanoma cells and displays antitumor activity in vivo. Biochem. Biophys. Res. Commun. 467, 928-934. https://doi.org/10.1016/j.bbrc.2015.10.041.

Gonçalves, M.J., Tavares, A.C., Cavaleiro, C., Cruz, M.T., Lopes, M.C., Canhoto, J., Salgueiro, L., 2012. Composition, antifungal activity and cytotoxicity of the essential oils of Seseli tortuosum L. and Seseli montanum subsp. peixotoanum (Samp.) M. Laínz from Portugal. Ind. Crop. Prod. 39, 204-209.

Gornish, E.S., Miller, T.E., 2010. Effects of storm frequency on dune vegetation. Glob. Chang. Biol. 16, 2668-2675. https://doi.org/10.1111/j.1365-2486.2009.02144.x.

Hanahan, D., Weinberg, R.A., 2011. Hallmarks of cancer: the next generation. Cell 144 (5), 646-674. https://doi.org/10.1016/j.cell.2011.02.013.

Hassan, S.B., Gali-Muhtasib, H., Göransson, H., Larsson, R., 2010. Alpha terpineol: a potential anticancer agent which acts through suppressing NF- $\mathrm{kB}$ signalling. Anticancer Res. 30, 1911-1919. https://doi.org/10.1515/chem-2018-0040.

Ju, J.B., Kim, J.S., Choi, C.W., Lee, H.K., Oha, T.K., Kim, S.C., 2008. Comparison between ethanolic and aqueous extracts from Chinese juniper berries for hypoglycaemic and hypolipidemic effects in alloxan-induced diabetic rats. J. Ethnopharm. 115 (1), 110-115.

Kalimuthu, S., Se-Kwon, K., 2013. Cell survival and apoptosis signaling as therapeutic target for cancer: marine bioactive compounds. Int. J. Mol. Sci. https://doi.org/10 3390/ijms14022334.

Kozan, E., Küpeli, E., Yesilada, E., 2006. Evaluation of some plants used in Turkish folk medicine against parasitic infections for their in vivo anthelmintic activity. J. Ethnopharmacol. 108 (2), 211-216.

Küpeli, E., Kartal, M., Aslanb, S., Yesilada, E., 2006a. Comparative evaluation of the antiinflammatory and antinociceptive activity of Turkish Eryngium species. J. Ethnopharmacol. 107 (1), 32-37.

Küpeli, E., Tosun, A., Yesilada, E., 2006b. Anti-inflammatory and antinociceptive activities of Seseli L. species (Apiaceae) growing in Turkey. J. Ethnopharmacol. 104 (3), 310-314

Kusari, S., Zühlke, S., Spiteller, M., 2011. Chemometric evaluation of the anti-cancer prodrug podophyllotoxin and potential therapeutic analogues in Juniperus and Podophyllum species. Phytochem. Anal. 22 (2), 128-143.

Lawrence, B.M., 1995. The isolation of aromatic materials from natural plant products. In: Tuley De Silva, K. (Ed.), Manual of the Essential Oil Industry, pp. 57-154.

Lesjak, M.M., Beara, I.N., Orcic, D.Z., Anackovb, G.T., Balog, K.J., Franciskovic, M.M., Mimica-Dukic, N.M., 2011. Juniperus sibirica Burgsdorf. as a novel source of antioxidant and anti-inflammatory agents. Food Chem 124 (3), 850-856.

Loizzo, M.R., Saab, A., Tundis, R., Statti, G.A., Lampronti, I., Menichini, F., Gambari, R., Cinat, J., Doerr, H.W., 2008. Phytochemical analysis and in vitro antiviral activities of the essential oils of seven Lebanon species. Chem Biodivers 5 (3), 461-470.

Lone, S.H., Bhat, K.A., Bhat, H.M., Majeed, R., Anand, R., Hamid, A., Khuroo, M.A., 2014. Essential oil composition of Senecio graciliflorus DC: comparative analysis of different parts and evaluation of antioxidant and cytotoxic activities. Phytomedicine 21, 919-925. https://doi.org/10.1016/j.phymed.2014.01.012.

Meot-Duros, L., Cérantola, S., Talarmin, H., Le Meur, C., Le Floch, G., Magné, C., 2010. New antibacterial and cytotoxic activities of falcarindiol isolated in Crithmum maritimum L. leaf extract. Food Chem. Toxicol. 48 (2), 553-557.

Miller, K.D., Siegel, R.L., Lin, C.C., Mariotto, A.B., Kramer, J.L., Rowland, J.H., Stein, K.D., Alteri, R., Jemal, A., 2016. Cancer treatment and survivorship statistics, 2016. CA A Cancer J. Clin. 66, 271-289. https://doi.org/10.3322/caac.21349.

Morshedloo, M.R., Quassinti, L., Bramucci, M., Lupidi, G., Maggi, F., 2017. Chemical composition, antioxidant activity and cytotoxicity on tumour cells of the essential oil from flowers of Magnolia grandiflora cultivated in Iran. Nat. Prod. Res. 31, 2857-2864. https://doi.org/10.1080/14786419.2017.1303699.

Murray, P.M., Moane, S., Collins, C., Beletskaya, T., Thomas, O.P., Duarte, A.W., Nobre, F.S., Owoyemi, I.O., Pagnocca, F.C., Sette, L.D., McHugh, E., Causse, E., Pérez-López, P., Feijoo, G., Moreira, M.T., Rubiolo, J., Leirós, M., Botana, L.M., Pinteus, S., Alves, C., Horta, A., Pedrosa, R., Jeffryes, C., Agathos, S.N., Allewaert, C., Verween, A.,
Vyverman, W., Laptev, I., Sineoky, S., Bisio, A., Manconi, R., Ledda, F., Marchi, M., Pronzato, R., Walsh, D.J., 2013. Sustainable production of biologically active molecules of marine based origin. New Biotechnol. 30 (6), 839-850.

Nagai, H., Kim, Y.H., 2017. Cancer prevention from the perspective of global cancer burden patterns. J. Thorac. Dis. 9, 448-451. https://doi.org/10.21037/jtd.2017.02.75.

Naili, M.B., Alghazeer, R.O., Saleh, N.A., Al-Naijar, A.Y., 2010. Evaluation of antibacterial and antioxidant activities of Artemisia campestris (Astraceae) and Ziziphus lotus (Rhamnacea). Arabian J. Chem. 3 (2), 79-84.

Nakanishi, T., Iidaa, N., Inatomia, Y., Murataa, H., Inadaa, A., Muratab, J., Langc, F.A., Iiunumad, M., Tanaka, T., 2004. Neolignan and flavonoid glycosides in Juniperus communis var. depressa. Phytochemisty 65 (2), 207-213.

Pimenov, M.G., Leonov, M.V., 1993. The genera of the Umbelliferae. A nomenclator 156 Royal Botanic Gardens, Kew.

Pires, I.M., Bencokova, Z., Milani, M., Folkes, L.K., Li, J.-L., Stratford, M.R., Harris, A.L., Hammond, E.M., 2010. Effects of acute versus chronic hypoxia on DNA damage responses and genomic instability. Can. Res. 70, 925-935. https://doi.org/10.1158/ 0008-5472.CAN-09-2715.

Pires, I.M., Olcina, M.M., Anbalagan, S., Pollard, J.R., Reaper, P.M., Charlton, P.A., McKenna, W.G., Hammond, E.M., 2012. Targeting radiation-resistant hypoxic tumour cells through ATR inhibition. Br. J. Canc. 107, 291-299. https://doi.org/10. 1038/bjc. 2012.265.

Poujade, F.-A., Mannion, A., Brittain, N., Theodosi, A., Beeby, E., Leszczynska, K.B., Hammond, E.M., Greenman, J., Cawthorne, C., Pires, I.M., 2018. WSB-1 regulates the metastatic potential of hormone receptor negative breast cancer. Br. J. Canc. 118, 1229-1237. https://doi.org/10.1038/s41416-018-0056-3.

Ramadan, M.M., Ali, M.M., Ghanem, K.Z., El-Ghorabe, A.H., 2015. Essential oils from Egyptian aromatic plants as antioxidant and novel anticancer agents in human cancer cell lines. Grasas Aceites 66, e080. https://doi.org/10.3989/gya.0955142.

Reutter, L., 1923. Traité de Matière Médicale et de Chimie Végétale. Paris Librairie J.B. Baillère et Fils, Paris, France.

Roos, W.P., Thomas, A.D., Kaina, B., 2016. DNA damage and the balance between survival and death in cancer biology. Nat. Rev. Canc. 16, 20-33. https://doi.org/10. 1038/nrc. 2015.2.

Sassi, A.B., Skhiri, F.H., Bourgougnon, N., Aouini, M., 2008. Antiviral activity of some Tunisian medicinal plants against Herpes simplex virus type 1. Nat. Prod. Res. 22 (1), 53-65.

Schneider, C.A., Rasband, W.S., Eliceiri, K.W., 2012. NIH Image to ImageJ: 25 years of image analysis. Nat. Methods 9, 671-675. https://doi.org/10.1038/nmeth.2089.

Seal, S., Chatterjee, P., Bhattacharya, Sushmita, Pal, D., Dasgupta, S., Kundu, R., Mukherjee, S., Bhattacharya, Shelley, Bhuyan, M., Bhattacharyya, P.R., Baishya, G., Barua, N.C., Baruah, P.K., Rao, P.G., Bhattacharya, Samir, 2012. Vapor of volatile oils from Litsea cubeba seed induces apoptosis and causes cell cycle arrest in lung cancer cells. PloS One 7, 1-11. https://doi.org/10.1371/journal.pone.0047014.

Seca, A.M.L., Silva, A.M.S., 2005. The Chemical Composition of the Juniperus Genus (1970-2004). Phytomedicines 16, 401-522.

Sever, R., Brugge, J.S., 2015. Signal transduction in cancer. Cold Spring Harb. Perspect. Med. 5, a006098. https://doi.org/10.1101/cshperspect.a006098.

Shahat, E.A., Bakr, R.O., Eldahshan, O.A., Ayoub, N.A., 2017. Chemical composition and biological activities of the essential oil from leaves and flowers of Pulicaria incisa sub. candolleana (Family Asteraceae). Chem. Biodivers. 14, e1600156. https://doi.org/ 10.1002/cbdv.201600156.

Sharifi-Rad, J., Sureda, A., Tenore, C.G., Daglia, M., Sharifi-Rad, Mehdi, Valussi, M., Tundis, R., Sharifi-Rad, Marzieh, Loizzo, R.M., Ademiluyi, O.A., Sharifi-Rad, R. Ayatollahi, A.S., Iriti, M., 2017. Biological activities of essential oils: from plant chemoecology to traditional healing systems. Molecules 22, E70. https://doi.org/10. 3390/molecules22010070.

Suhail, M.M., Wu, W., Cao, A., Mondalek, F.G., Fung, K.-M., Shih, P.-T., Fang, Y.-T, Woolley, C., Young, G., Lin, H.-K., 2011. Boswellia sacra essential oil induces tumor cell-specific apoptosis and suppresses tumor aggressiveness in cultured human breast cancer cells. BMC Compl. Alternative Med. 11, 129. https://doi.org/10.1186/14726882-11-129.

Sylvestre, M., Legault, J., Dufour, D., Pichette, A., 2005. Chemical composition and anticancer activity of leaf essential oil of Myrica gale L. Phytomedicine 12, 299-304. https://doi.org/10.1016/j.phymed.2003.12.004.

Tacar, O., Sriamornsak, P., Dass, C.R., 2013. Doxorubicin: an update on anticancer molecular action, toxicity and novel drug delivery systems. J. Pharm. Pharmacol. 65, 157-170. https://doi.org/10.1111/j.2042-7158.2012.01567.x.

Tilaoui, M., Mouse, H.A., Jaafari, A., Zyad, A., 2015. Comparative phytochemical analysis of essential oils from different biological parts of artemisia herba alba and their cytotoxic effect on cancer cells. PloS One 10, 1-15. https://doi.org/10.1371/journal. pone. 0131799 .

Tosun, A., Baba, M., Bahadir, O., Okuyama, T., 2006. Coumarins isolated from the roots of Seseli resinosum in Turkey. Pharm. Biol. 44, 528-533.

Tsoukatou, M., Vagias, C., Harvala, C., Roussis, V., 2000. Essential oil and headspace analysis of the maritime Bombycilaena erecta and Otanthus maritimus species growing wild in Greece. J. Essent. Oil Res. 12, 360-364.

Zanoni, M., Piccinini, F., Arienti, C., Zamagni, A., Santi, S., Polico, R., Bevilacqua, A., Tesei, A., 2016. 3D tumor spheroid models for in vitro therapeutic screening: a systematic approach to enhance the biological relevance of data obtained. Sci. Rep. 1-11. https://doi.org/10.1038/srep19103.

Zhou, H.J., Wang, W.Q., Wu, G.D., Lee, J., Li, A., 2007. Artesunate inhibits angiogenesis and downregulates vascular endothelial growth factor expression in chronic myeloid leukemia K562 cells. Vasc. Pharmacol. 47, 131-138. https://doi.org/10.1016/j.vph. 2007.05.002. 